\title{
Privatization and Performance: Cognitive and Behavioral Governance,
}

\section{Review and Proposition of A New Field of Analysis}

\author{
Mouna MRAD (corresponding author) \\ Department of Finance, Higher Institute of Management \\ 41, rue de la liberté, Bouchoucha-2000 Bardo \\ Tel: 216-98-685-166 E-mail:mrad_m@hotmail.fr
}

Slaheddine HALLARA

Higher Institute of Management, Department of Finance

41, Rue de la liberté, Bouchoucha - 2000 Bardo

E-mail: slaheddine.hallara@isgt.rnu.tn

The authors are grateful to Dr Anouar BEN MABROUK for his valuable comments

\begin{abstract}
We examine the literature of corporate governance to investigate the impact of corporate governance mechanisms on performance improvement of the newly privatized companies. We notice that all researches studying this impact considered only the disciplinary angle of governance and omitted the most important one which is the vision based on a cognitive theory of governance. So, we present limits addressed in the literature to the financial approach of governance and show the necessity to incorporate in our analysis both the disciplinary and the cognitive approach for a complete study of this impact.
\end{abstract}

Keywords: Privatization, Corporate governance, Performance

\section{Introduction}

There is a large and fast evolutionary stream studying the impact of the ownership structure on the performance. The greater part of the literature considers that the ownership structure of the company has a significant effect on the corporate governance and on the performance, since the work of Berle and Means (1932) in the thirties. The main concern was the separation cost of ownership and control, or the agency costs (Jensen and Meckling 1976, Fama and Jensen 1983).

The majority of the empirical and theoretical studies dealing with the impact of privatization on the performance have tried to analyze this impact based on the lode of disciplinary governance. The latter has been considered as a key determinant of the privatization program success. Shleifer \&Vishny (1997) mentioned in their study that the corporate governance may explain the success or the failure of a privatization process. Johnson and Shleifer (2003) awarded the mitigated records of privatizations in the transition economies to the weaknesses in the corporate governance mechanisms, in particular, the low investor protection. Their conclusions have thus converged on the fact that the improvement of the economic performance is often attributed to changes in the governance systems. These changes that affect both the external and internal components, are supposed to act on one hand, in a traditional way, accentuating the disciplinary pressures on the leaders. On the other hand, and more positively they act by increasing the latitude in strategic or financial decisions.

So we can say that privatization is supposed to imply a more important discipline, a reconfiguration of the shareholder, a change of governing bodies and changes in relation with the shareholders.

However, the studies on strategy inform us that the disposition of a company to create and sustain the value is not limited to a question of discipline of potentially opportunistic leaders. On the contrary, the organizational aptitude, the knowledge and the specific skills of the manager and its teams are considered as potential vectors of a competitive and permanent advantage and, thereby, of the creation of this value, hence the emergence of a new approach called the cognitive approach. In fact, the cognitive approach differs from the financial approach which is based on a different approach of the firm. The latter is no longer modeled only as a node of contracts but also as a "knowledge repertory". According to Charreaux (2002): "the cognitive approach led to study the governance systems in the light of their influence on the cognitive dimensions of the value creation, the opportunities for growth perception, the cognitive coordination, and the organizational learning". His approach led to the analysis 
of the relations between leaders and shareholders under the cognitive angle, an angle ignored or passed over by the financial approach of governance, where the shareholder is more reduced to a simple financial investor.

\section{Research Problematic}

The privatization proposed as the passage of a public organization to a private organization is not only a worldwide phenomenon, combining the basic link between property and performance but also a major change in the life of an organization, including a vector of technology and skills transfer.

Therefore can be asked: whether the new governance mechanisms induced by privatization can constitute a body of cognitive transfer and hence creators of value at the level of the privatized company? Furthermore, under which conditions the governance can play in a privatization context, a role in the opportunities construction of value creation, whose perception and implementation are extremely related to the specific skills of a firm and its leaders?

It appears from our study that the problematic of governance in the newly privatized companies must not be considered only under the disciplinary angle. The Innovation, the creativity, the discovery of new issues related to new devices of governance, the continuing evaluation of actions and their opportunity are also some mechanisms to privilege. This type of mechanisms corresponds to a vision based on a cognitive theory of governance.

Thus, the disciplinary approaches alone are not sufficient to account in a perfect way for governance in privatized enterprises. The approach which can be approved is rather a global approach, i.e., involving both the disciplinary mechanisms and cognitive mechanisms.

It is, in the framework of the present paper, to renew the analysis in recognizing the cognitive role of governance mechanisms which allows to modify significantly both the habitual analysis of the property structure and the traditional governance vision.

\section{Theoretical Analysis: Privatization and cognitive governance}

Privatization implies the introduction of new actors within the divested company inducing by this fact substantial cognitive change within the organization. As it was advocated by Vermeulen and Barkema (2001), the resumption of another company is a carrier of new knowledge and new resources. In parallel, Harrison et al. (1991) argued that the differences between the organizations are sources of opportunities, synergies and learning. We can thus assume that privatization in the extent of inducing the approximation of different stakeholders at the level of the organization is likely to be carried out in terms of more important inputs and more diversified skills, than in the development field. The confrontation of knowledge, experiences and expertise of managers and administrators for example, could lead to a strengthening of skills.

Several empirical studies have tried to test the impact of disciplinary governance mechanisms both external and internal in the performance determination of privatized firms. These results, although advocating on the great majority in favour of a positive impact of these mechanisms on the post privatisation performance, seem to be restricted and does not take into account an important aspect of governance which is the cognitive one. In fact, several recent works have been unveiled the fact that the traditional governance approach is a relatively narrow conception of the value creation, since it is purely disciplinary (Charreaux, 2002a, 2002b; Ricart, 2000). Thus, most of the traditional positive theories of agency models consider investment opportunities as a given set. However, the research in strategy emphasizes the central role of knowledge, capacities and skills (Kogut and Zander, 1992; Nonaka 1994; Business and Hamel, 1990; Rumelt 1984; Teece et al. 1997), tacit, to stimulate innovation and comfort a competitive advantage, which would be as much of potential vectors of a lasting value creation.

It is in the following development to expose the different passages in the theory of governance which have led to the emergence of cognitive and behavioral governance while specifying the limits due in particular to the ignorance of the cognitive dimension of the different governance mechanisms. In a second step, it is to show to what extent the introduction of the cognitive dimension allows to light up our analysis by highlighting some fields not exploited by the disciplinary theory.

\subsection{Theories of governance: from Financial to cognitive and behavioral one}

\subsection{1.from a shareholder approach to a partnership approach}

The objective of this present development is to proceed to a synthetic presentation to extract the consistent elements that can guide to our reflection. 
Whatever the theoretical bases which subtend them, mechanisms of governance have been established in the only goal of the contribution to the business efficiency improvement and hence the establishment of value maximization. Thus we discriminate under these theories the current disciplinary from the current cognitive. The disciplinary current relies on two theoretical approaches: the shareholder theory and the partnership governance theory. We will discuss them hereafter.

\subsubsection{The shareholder theory of governance}

For a long time, the analysis about the corporate governance has concerned the only relations between shareholders and managers in considering only conflicts of interest between these two elements. From a conceptual point of view, the shareholder theory of the governance covers the normative branch of the agency theory. Thus, the creation of the value goes only upon the discipline of the leader. Hence, the objective of the governance system would be to establish a number of mechanisms to discipline the leader and to limit its discretionary space and to secure the financial investment of shareholders and to create a maximum value at the level of the company.

Fama (1980) proposed for the managerial firms a model of governance system which becomes at the basis of the dominant view of governance. According to Charreaux (2002), the system of governance shareholder « in the Fama's sense » may be represented in the following table.

(Insert Table 1 Here.)

Thus, according to Fama, the most important mechanism is the market for directors, completed by the board of directors and the mutual monitoring of managers and, in last place, by the control market. This theory inspired by the Anglo-Saxon managerial firm has several limits. For Charreaux (2004): "it does not explain the functioning of the non-Anglo-Saxon system"(Note1), specially the economies of non-Anglo-Saxon countries where the State and the banks have a major role in the financing of firms, hence the enlargement of the concept of governance at all the parties intervening in the company. Due to the limits attributed to shareholder model and which may notes its lack of realism or misunderstanding of the relationship between disciplinary systems of leaders in the shareholder performance and in the extent that it does not allow to understand the structure and functioning of the non-Anglo-Saxon systems, it has proved necessary to explore other channels. Therefore this bilateral vision poorly reflects the complexity of the organizational life and ignores the take into consideration of the aspirations and interests of other groups of actors in the company. The recent developments in the agency theory registering in a wider vision, introduce the other partners (stakeholders) in their analysis.

\subsubsection{Enlargement of governance partnership theory to the whole parts of stakeholders}

The theory of partnership governance leads to the incorporation of the whole parts of the company stakeholders in the creation and distribution process of the value. Contrarily to the shareholder approach, within the partnership theory, the shareholder is not the only residual residual claimant, the approach is expanding to all company partners (employees, customers, suppliers ...). But the distribution of the value also involves the discipline of manager. In continental Europe, the corporate governance systems attribute to stakeholders such as the banks and the non managers employees, a formal role in governance. In Germany, banks play an important role in the control of companies, as most of the individual shareholders delegate their voting rights to a bank, which then vote, in meetings of shareholders on behalf of their customers. In addition, the firms maintain often steady reports with their bank which can hold an equity degree. The banks have access to the internal information, which enables the detailed control and gives them a central role in monitoring process. Japan has a similar system of governance and based on the governance of bank such model known as German-Japanese governance model.

However, a global trend during the past decades has led to a more legal protection of shareholders and has reduced the governance role of banks. For example, German banks deprive their shares of ownership in non-bank business. The researchers focus on the existence of multiple stakeholders other than the capital owners in adopting the perspective of "stakeholders". A stakeholder is a group or an individual who can affect or is affected by the achievement of the firm's objectives (Freeman 1984). Three traditions of the research for the stakeholder have been developed such as instrumental, normative and descriptive (Donaldson and Preston 1995). The instrumental approach argues that if the managers view the interest of stakeholders in possessing merits intrinsic values, this would facilitate the performance of the company as considered by the perspective of the shareholder (Jones 1995).

The normative perspective of shareholders intersects with the ethics literature. It starts from the presumption that managers have a moral duty to consider stakeholders other than shareholders (Evan and Freeman 1990, 
Donaldson and Preston 1995). Finally, the descriptive perspective starts from the fact that stakeholders exist and they affect the management of the company. This literature analyzes theoretically and/or empirically which stakeholders should include and how (Brenner and Cochran 1991, Mitchell et al. 1997).

Nowadays, the company is considered as a node of contracts or a coalition, assembling various providers of resources whether human or material to create a pension organization. The governance system appears as a way to preserve the interests of all stakeholders (shareholders, managers, creditors, employees, suppliers, customers, banks ...). So, although this theory has a better explanatory value, it is nevertheless based on a static vision of efficiency in the extent that the process of creating value, through learning and innovation, remains unexplored.

\subsubsection{The emergence of cognitive and behavioral governance:}

Compared to the two first theories which have a more static vision on value creation, the cognitive approach provides a dynamic view. Each of these theories provides a different conception of governance and mechanisms to implement and indicates different modes of value creation.

\subsubsection{Limitations of the legal approach to financial governance}

The exploration of the cognitive role that shareholders can play leads to a critic of the legal financial approach of governance. In the latter, derived from the contractual representation of the firm associated with the particular agency theory, the primary objective of the governance system is to minimize agency costs resulting either from conflicts of interest in cooperative situations or the expropriation of gains related to the dominance of the dominant shareholders. The costs are equal to the sum of those for design, implementation and maintenance of incentive systems and control and the residual loss, in other words, of the shortfall related to the imperfect resolution of these conflicts,

Despite this theory, rationality was not appreciated according to the decisions but rather on the processes which govern them. Thus, in this current, the source of efficiency of the firm is disciplinary; such a framework ignores the action on the value creation through cognitive way including construction of investment opportunities.

The current cognitive contrarily leads to analyze the relationship between managers and shareholders by considering cognitive contribution. Such aspect has been totally ignored by the financial approach to governance, the latter gives to the shareholder the simple role of financial investor. Nevertheless, the integration of these cognitive dimensions especially in the analysis of the role of shareholders does not mean for all that the corresponding dimensions to the conflicts of interest and ownership would be overlooked, of course, the two perspectives are complementary and can enrich one another. Moreover, the fact of taking into account the two dimensions, disciplinary and cognitive, leads toward a synthetic theory of governance (Charreaux, 2002). Roe (2003) has made at his criticism on legal and financial model of governance the fact that these mechanisms arrive to reduce the costs of agency due to the opportunism, they fail to consider mismanagement manifested for example, by a sub-optimal exploitation of investment opportunities. Thus from a cognitive optics, Charreaux (2002) defined corporate governance as the set of mechanisms that have the potential of value creation through learning and innovation.

\section{(Insert Table 2 Here.)}

In this theoretical approach to governance, value creation depends in priority on the identity and skills that are conceived as a coherent whole (Teece et al 1997, cited by Charreaux, 2002). Similarly, the pattern of creation and ownership of the value behind it differs from that underlying the disciplinary theories. In this approach, the company is no longer perceived as a node of contracts or a coalition, but rather as a knowledge repertory able to perceive new opportunities and create value in a sustainable manner.

\subsubsection{The firm as a knowledge repertory}

The cognitive role of shareholders is based on a different conception of the firm while departing completely from the approach of financial governance. This one is no longer specified as a node of contracts but also as a "Knowledge repertory", the two approaches not being inevitably incompatible. The theoretical basis of this representation draws its inspiration from the cognitive theories of the firm who combine evolutionary economic theory, behavioral organization theory and strategic theory of resources and skills. Through this new approach, the source of the efficiency of a firm is no longer disciplinary, but cognitive. It creates value through its ability and its capacity to minimize the cognitive conflict and thus to innovate through the construction of growth opportunities. The opportunities are no longer considered as exogenous but as being created. The perceptual dimension of the entrepreneurial function completely ruled out in the legal and financial approach is particularly important in this current that can be associated with authors such as Prahalad (1994) and O'Sullivan (2000). 
The cognitive approach tends then to examine the governance systems based on their influence on the cognitive dimensions of value creation, the perception of growth opportunities, cognitive coordination and organizational learning.

\subsection{Governance mechanisms and value creation}

Privatization leads to the establishment of new actors and new governance mechanisms within the company. The evolution of both internal and external governance systems driven by privatization, suggests numerous ways through which the privatisation can lead to an improvement of performance. At the same time privatization is followed by a change in the internal organizational architecture that is the decision allocation and control systems (Catelin and Chatelin 2001). It ensures therefore the emergence of new forms of ownership that are missing within the public companies.

We can then assume that the improved economic performance is often attributed to changes in governance systems that accompany them. These changes that affect both external and internal components, are expected to act on the one hand, strengthening the disciplinary pressures on leaders, on the other hand and more positively, by increasing the transfer of knowledge and know-how through these mechanisms to different members of the organization, and especially the manager.

\subsubsection{The Board of Directors as a cognitive transfer organ}

Privatization generates changes at the level of the internal components of governance systems. These changes are presumed not to act only by increasing the disciplinary pressures on the leaders in order to compel them to run in the interest of shareholders but also by generating cognitive flows through such mechanisms.

Charreaux and Alexandre (2004) had noticed in the case of the French privatization, that this one has been accompanied by a profound reorganization of the board. The new ownership structure resulting from the privatization would lead to a decentralization of decision-making process which involves the adaptation of supervisory bodies, particularly the board of directors. The development of internal systems, found throughout this organ, console the idea of a strengthening of the control of leaders even if it doesn't need to exaggerate the importance of the role of disciplinary councils. Such an exclusively disciplinary conception, fails to reflect the cognitive perspective associated with new skills and knowledge transfer.

In the new approach of governance, the role of the board of directors is no longer limited to a simple mechanism for monitoring, but may also include a cognitive dimension. Its role is expanding then to that of aid to the construction of the strategic vision and its implementation and thus the participation in decision-making. This can at least be considered in certain situations, as a place of development and individual and collective learning even organizational, allowing the manager to ensure the acquisition of additional managerial capacity. So, it can help the leader through the debates, to detect or to build growth opportunities, to build, enrich and even revise its strategic through the confrontation of its cognitive scheme and those of administrators (Charreaux, 2002).

In dealing with some problems or questions, a leader cannot always discuss it with his subordinates, and is directed more toward the board of directors to assemble advices and opinions (Mace, 1971, Mintzberg, 2003). A study was conducted by Charreaux and Pitol-Belin (1989) on a sample of French firms. It consisted of 107 questionnaires sent to their boards. The analysis of data revealed that for $74 \%$ of managers interviewed, the board of directors has been envisaged as being a body of reflection assisting to the preparation of decisions that may influence the strategy. This body claimed in the three quarters of cases, for the crucial decisions such as diversification, acquisitions and disposals of assets. Similarly the authors contemplate that $26 \%$ of boards specify strategic objectives in the medium long-term of the firm without content to ratify them.

It seems however, that the contribution of the board in decisions and strategic planning varies across countries and economic contexts. We may notify for example that strategic planning is a fundamental concern for $37 \%$ of French board of directors against 63\% for Americans (Charreaux and Pitol- Belin, 1989). We must also emphasize that the formal changes such as the percentage of independent directors, the number of committees, are significant only if they are accompanied by a functional efficiency, related to how the board ensures missions, particularly in terms of preventing and resolving crises.

In fact, several investigations have revealed that the competence was one of the first criteria for recruitment of administrators, hence the possibility of creating value through knowledge transfer, and since the board is one of the mechanisms and even more the most important to have supported the decisions of leaders, therefore, the decisions made by it would be more effective. Hence there will be value creation through improving the quality of decisions and good seizing of management opportunities by acquiring additional managerial capacity. Rindova (1999) postulated that the incidence and importance of managerial skills in strategic decisions can be 
deferred to those of directors. They contribute to reduce uncertainty and complexity associated with strategic decisions; through their expertise in solving problems, they can contribute to different stages of decision-making process, such as the exploration of possibilities, their interpretation and the final choice. The same view was shared by Castanier and Helfat (2001), arguing that board members are involved in various degrees to the strategic decision making in light of their characteristics and their previous professional experience. Indeed, one reason was often put forward to explain the poor performance of public enterprises is the low qualification of board members and directors (Lopez-De-Silanes, 1997). Their role was the full compliance with regulations and the satisfaction of objectives imposed by the State which may be in the majority of cases social rather than economic.

During privatization, the low-skilled managers can be viewed by other organizations whose objectives are more aligned with profit maximization and new monitoring mechanisms can be put in place by the new shareholders (Boubakri et al 2001). These laters have to admit that the restructuring of the board and the change of the CEO can be considered as potential determinants of the variation in performance associated to privatization. Besides, as it was mentioned by Mintzberg (2003) at its resumption on Pfeffer's work (1972), the selection of directors would not be at random but it is rather according to the service needs of the company, and presenting it mainly as a contribution of skills rather than a provision of a power game. Hence we can conclude that following privatization there will not be value creation only by improving the disciplinary authority, but also by cognitive transfer from the monitoring body to the various stakeholders at the level of enterprise especially the leader. One of the obvious functions of the board is to establish contacts for the organization. Administrators once appointed bring their networks and can break through some doors (Mintzberg, 2003). They may also play a role in the evolution of the firm reputation, given the titles and the prestige which they combine (Mace, 1971).

Nevertheless, the impact of the structure of the board of directors on its involvement in the company's strategy doesn't make today the subject of consensus. Although the presence of independent directors on the board of directors has taken for a long time a growing importance because, among other, various financial scandals, several recent studies have confirmed a lack of independent directors influence on the performance such as Lawrence \& Stapledon (1999) and Alexander and Paquerot (2000). In Accordance, Whestphal (1998) has concluded to the existence of weak evidence of this link. Thus, despite the fact that the lack of independence of boards of directors was probably considered as the main cause of their ineffectiveness (Godard \& Schatt (2004)), in no way they can ensure that independent directors have enough expertise to assess the relevance of managerial decisions or to contribute to their elaboration. Hill and Snell (1988) have argued that boards of directors dominated by the internal stimulate innovation as long-term strategy, while those with a majority of external induce more diversification. They are also regarded as a source of various skills, in terms of training, professional and organizational experience (Milliken and Martins, 1996). Their contribution would be particularly positive when they engage in other enterprises having similarities with the one in which they are directors, for example in the field of organization or markets (Melcher, 1996).

Furthermore, several empirical studies have shown that even if the independence of directors is likely a necessary condition for the creation of value for the company it is not a sufficient one (Becht et al. 2005; Bhagat and Black, 1999.2000). Morck (2004) proclaimed that the formal independence of directors is insufficient; as they usually have a sense of loyalty towards the legitimate authority hence they will not exercice a perfect control of the leader (Note 2).

We can emerge from all above, that the criteria for analyzing the quality of a board of directors would not should be designed in terms of independence, but of diversity and cognitive contributions. In addition, the fact of strengthening the role of directors in order to better involve them in the company's strategy represents an important channel for creating value, it remains unaffordable in the context of public enterprises within which such a body is still considered passive. Generally, the public board of directors specifies by various public decision-making centers, sometimes informal and by the representation of several partners. These directors are in fact representatives of the state. Such representatives are designated by the employees and qualified persons appointed by the public authorities. In addition, conflict resolution shall establish in the ministerial offices in the context of informal meetings. Similarly, the fact that the leader is designated by the public authorities confers on the board of directors a more supporting role than that of disciplinary measure.

Furthermore, the mandate of the leader is more related to the electoral deadlines than to the decisions of revocation by its employers. All these particularities attached to the public board of directors make that its functions would be reduced compared to the board in private frame. It seems therefore to play the role of a house of registration compared with its role in controlled private companies. Catelin and Chatelin (2001) have postulated that privatization changes the role nature of the board of directors' control by enhancing the 
functional separation between decision and control in favor of the management team. Such control function which is limited in the public enterprise, becomes after privatization based on the effective practice of the real function of decisions approbation. Indeed, Fama and Jensen (1983) designated four stages in the decision making process of organizations: the initiative, ratification, the implementation and monitoring. The decision function derived from the unification of the initiative and implementation functions, while that of control from the assembly of ratification and monitoring functions. Initiative step is divided into two sub-stages: the projects elaboration and the definition of all possible choices. The various mechanisms of governance act differently during these stages.

The board of directors occurs during the development stage projects in which the mechanisms operate to varying degrees on the cognitive development of leaders. The leader develops its projects according to their mental processes which are conditioned by his training, experience, internal and external networks of relationships, but also by market conditions and the information that is transmitted to him, including the specific information. The specific mechanisms such as the board of directors and confidence networks play an important role. This step is not discussed, particularly in the financial literature where most often, projects are considered as exogenous and pre-existing. According to Andrews (1980), a reflection guided jointly by the board of directors and the manager on the strategy seems advisable for two reasons: firstly, the directors, participating in the development of strategies at the level of the firm will increase the development and the creativity of its strategy through their experiences. Secondly, they will accomplish more efficiently their role of monitoring and control if they were more involved in the strategy of the firm. In addition, the experience of other boards or other functions concedes to administrators to be important sources of information for the firm (Mizruchi, 1996, Palmer et al. 1993). Belonging to several boards provides to administrators an important source of information on practices and policies of firms (Mizruchi, 1996). It is in fact a determinant positively associated with perception of the directors' ability to contribute to the board discussions (Carpenter and Westphal, 2001, P. 649). Even, when the administrators sit on the board of several companies, their involvement in the strategy of the firm would generally be higher (Carpenter and Westphal, 2001). Meanwhile, the fact that directors are derived from different backgrounds confers them susceptibility at the origin of two kinds of inputs: information and knowledge, and skills on the other hand. Hence their participation in the strategies of the company implies that the studied alternatives would be numerous and lead to more creative solutions when the firm enjoys of a cognitive variety (Milliken and Martins, 1996). Similarly, knowledge and information that the board of directors may grant help to reduce the uncertainty in which the firm evolves (Rindova, 1999). Boards of directors including representatives of various stakeholders incite strategies development of organizational learning (Lazonick and O'Sullivan, 1998). In the same way, the multiplicity of mandates is often seen as a source of learning (Useem, 1982), and an enrichment of managers knowledge and skills enabling them to participate and to contribute effectively to the strategy of the firm, particularly in terms of diversification and internationalization (Carpenter and Westphal, 2001). However, it is seen by others as a factor in reducing the involvement of administrators, lack of time (Melcher, 1996).

\section{(Insert Table 3 Here.)}

During the privatization we rose from passive boards of directors in these public companies to boards more and more involved in the strategic development and creativity and innovation, hence the creation of value through this control organ by cognitive way would be evident.

However, we should not overlook the fact that the strongly involved board in corporate strategy can be a source of cognitive conflict by imposing its vision on the leader as it can contribute to the enhancement and development of the reflection of the leader; the two contingencies should then be envisaged. Some authors such as Pfeffer (1972) have contested the role attributed to the board of directors as an organizational development and provider skills. They postulated that the Boards do not engage in a consistent manner in the strategy of the company, some are passive, restricting their intervention to approve the decisions proposed by the leader.

In Button 2002, the authors stressed the fact that directors must have a real knowledge of businesses of the firm by mastering the strategic issues of the markets where it interferes. So, we can not emphasize enough the skill and experience which are the first qualities of directors. Judge and Zeithaml (1992) however, have found a positive relationship between the involvement of the board in the strategy and firm performance. So we must recognize that it does not create value only through the reduction of agency costs due to conflict of interests, but

\subsubsection{The manager Change}

During privatization, the low-skilled managers can be viewed by others whose objectives are more aligned with profit maximization and new monitoring mechanisms can be put in place by the new shareholders (Boubakri et 
al 2001). Thus, the restructuring of the board and the change of Chief Executive Officer (CEO) were considered as potential determinants of the variation in performance associated with privatization. Within the public firms, the state intervention can have a crippling effect on the leaders. They become by this fact state officials who must comply with its decisions and carry out its policy within the company, which creates a disempowerment of the leaders of public enterprises and a decrease in their latitude discretionary.

A different line of literature attributes the superior performance of private companies, not only to the motivation for agents, but also to the capacity of these companies to attract and select the most qualified managers (Rosen 1992, Barberis et al 1996). The effectiveness of the mechanisms of managers replacement can be crucial to restructure performance to the extent that the lack of managerial skills for the market economy is a major source of poor performance.

The importance of introducing new managers rather than creating stronger incentives for titulars was highlighted in two studies. Barberis et al. (1996), which represented one of the first main quantitative studies on the effects of privatization in Russia, analyzed 452 stores and found that the change of human capital stimulates restructuring. Similarly, Claessens and Djankov (1998) found that performance in the Czech Republic has been improved by changing the managers rather than providing their share holdings in order to encourage them. All their performance indicators are thereby negatively correlated with the length of tenure of the CEO, but positively correlated to the recruitment of external managers. Thus, neither Barberis et al (1996) nor Claessens and Djankov (1998) found evidence for the capital ownership by managers to be linked to improved performance.

Other studies, Such as, Earle and Estrin (1997a) and Jones (1998) found better performance for firms owned by managers. It may come from the above that the change of managers due to privatization would be more beneficial to improving performance through transfer of skills than through providing manager incentives in terms of stock options. So the idea advanced by the disciplinary approach, to give the leaders shares of equity in order to better involve them to act in the interest of the shareholders no longer has the object of a consensus today.

\subsection{Cognitive role of the shareholder and ownership structure}

The reconfiguration of the shareholders made during the privatization led to quite different ownership structures. According to Chatelin (2003), privatization represents a double change of the company ownership. First, it changes the nature of ownership through its transfer to private actors and implies a move from public domain to private one. Furthermore, it acts on its structure via the composition implicated by the first change. Privatization ensures thus the emergence of new forms of ownership which are missing within the public companies.

For a long time, the issues of interest conflicts between shareholders and managers and between major shareholders and minor ones have been addressed only under the disciplinary angle. In addition, the separation between owner and manager has been assumed complete according to Berle and Means (1932). The role of shareholders is that of assumption of financial risk. This assertion doesn't make the subject of a consensus. For example, Faccio and Lang (2002) have shown through their study on a sample of 13 European countries, that the average percentage of firms whose leaders derive from the dominant shareholder's family is $68.5 \%$ with extremes of $80 \%$ for Belgium and Austria and $50 \%$ for Portugal. Yielding a weakness of separation between owners and managers in the European countries. In addition, shareholders are the residual creditors and therefore the better able to specify the key factors of success within their companies. In this regard, Alchian and Demsetz (1972) postulated that the use of the term monitor is to evoke several activities in addition to its disciplinary implication. It involves measuring output performance, allocating rewards, observing the input behaviour of inputs and giving instructions in what to do and how to do it.

Therefore, the role of owners is no longer reduced to the simple discipline or the simple provision of financial capital; it is up to the strategy fixing and the effective way to combine the productive resources. With a very similar argument, according to Alchian and Demsetz (1972), the status of residual claimant is also justified by the need to encourage the contractor to effectively accomplish the active side of the property. That is, the managerial and perceptive functions due to the wide content of the supervisory role assigned to the contractor and associated with the passive dimension of ownership, yet not by the remuneration of risk linked to a financial contribution, (by Charreaux 2002) (Note 3). This view is rejected in the case of managerial firms where the separation between ownership and management is total. Hence the role of shareholders is restricted in this case to that of financial resources providers. For this reason the concentration of ownership was seen as a key driver of performance in privatized firms, since in this case the separation would be partial and the intervention of the owners in the management of the company would be obvious. Such a point cannot be validated for the public 
enterprises where the allocation of right assumption of the residual risk and residual decisions (Note 4) may involve several ministries concerned with the public firm diluting the incentive scope of this property rights. It would be the same concerning the residual gains and losses ownership. Thus, liability is greatly diluted in the case of public companies. Accordingly, it seems that the public property remains less efficient than private ownership in the light of this dilutive effect. Hence, the lack of transfer of knowledge and skills via the owners of such firms. Consequently, due to the transfer of public property to those of private, several forms of shareholding will appear in the company and will affect differently its performance. On another level, the new ownership structure after privatization (more diffuse shareholding) would lead to a decentralization of decision-making process which involves the adaptation of supervisory bodies, particularly the Board of Directors. Charreaux (2002) postulated that the contractor is not just a simple supervisor within the disciplinary meaning, it defines the tasks and select the persons who must perform within the cooperative node (Note 5).

The new design of governance devices by taking into account the managerial and perceptual dimensions of the shareholding leads to a different interpretation of ownership structures. The role of shareholders is no longer limited to a mere provision of financial resources. In addition, the separation between ownership and control is not complete in the reality. However, we must not ignore the possibility of the emergence of cognitive conflict following to this transfer of property between the former manager (if it keeps his post and has not been replaced) and new shareholders to the extent that the capacity of the latter to the exploitation of new skills and cognitive resources remains more or less great. These cognitive costs disappear if the former leader would be replaced by another.

Charreaux (2002) carried out the modification of the model proposed by Roe (2003) assuming that the owner-manager sells its control block to a shareholder of industrial type in search of some managerial and perceptive skills. Then he he proclaimed that the transfer of ownership to this one type of shareholder is generator of significant cognitive resources. But this point of view which limits the supply of skills to only industrial shareholders seems too limited for us, to the extent that there are other types of shareholders such as foreign investors in the case of privatization, which was considered as also providers of cognitive resources, skills and expertise. Such a cognitive transfer would be evident in the framework of public companies deemed to be deprived of skills and whose economic efficiency represents their last concern.

Bolbol et al (2004) have postulated that the relationship between large shareholders and the company's performance depends on the identity of the largest shareholders. They then divided the concentrated ownership structure into four separate groups of owners, namely domestic institutional investors, government, individual investors and foreign investors. They have thus detected that the concentration of the foreign ownership leads to the best value of the firm regarding as to other types of owners. These findings are consistent with theoretical arguments claiming that foreign investors bring the best practices of governance and monitoring in addition to the transfer of technology which increases the value of the firm. Thus, although according to Charreaux (2002), an industrial shareholder would be the most or even the only to be able to transmit its knowledge and skills than other type of shareholders. It seems to me, however, that the dominant shareholders (concentrated ownership), whether foreign or domestic, industrial or institutional will act differently on the performance of the privatized company in bringing new practices within the organization previously under inefficient public ownership.

\section{Conclusion}

In this paper, we have tried, to recognize the cognitive role played by governance mechanisms within privatized companies. This role has been ignored by the financial theory of governance which attributes the increase in performance only to disciplinary mechanisms limiting the discretionary power of leaders. We have thus resorted to a synthesis of the literature and we presented the various criticisms made to the financial approach, hence the need to renew such a framework of analysis by recognizing the role of these cognitive mechanisms of governance. Such mechanisms judged as key determinants of the performance improvement after privatization, should no longer be treated only under the disciplinary angle. The use of an analysis incorporating both the disciplinary and the cognitive approach would be complete and consistent.

The new ownership structure after privatization would lead to a decentralization of decision-making process which involves the adaptation of supervisory bodies, particularly the board of directors. Such a body with role being active as opposed to what it was within the public enterprises is being reconsidered as a place of development, individual and collective learning even organizational, thus leading to the acquisition of additional managerial capacity by the manager. Similarly the effectiveness of replacement of managers was seen as crucial to the restructuring of the performance after privatization. Low-skilled managers should be replaced by best 
skills and qualifications ones. Therefore, the mechanisms of motivation and incentives siled for a long time as the best way to align the interests of managers with those of shareholders is find outdated today.

Finally, the role of owners is no longer reduced to the simple discipline of leaders or a simple contribution to a financial capital, but it is rather recognized as a provider of knowledge resources through the setting of strategy and effective way to combine the productive resources. Such a transfer would be provided cognitive, in our opinion, during the privatization not only through industrial shareholders as approved by Charreaux (2002), but by all types of dominant shareholders, in particular industrial or foreigners. The fact that there is transfer of public property to private one creates value by cognitive way in any kind of shareholder.

\section{References}

Alchian, AA. \& Demsetz, H. (1972). Production, Information Costs, and Economic Organization. American Economic Review, 62(5), 777-795.

Alexandre, H. \& Paquerot, M. (2000). Efficacité des structures de contrôle et enracinement des dirigeants. Finance-Contrôle-Stratégie, 3(2), 5-29.

Alexandre, H. \& Charreaux, G. (2004).L'efficacité des privatisations françaises: une vision dynamique à travers la théorie de la gouvernance. Revue économique, 55(4),791-821.

Andrews, K. (1980). Directors Responsibility for Corporate Strategy. Harvard Business Review, November-December, 112-119.

Baghat, S. \& Black, B. (1999). The Uncertain Relationship Between Board Composition and Firm Performance. Business Lawyer, 54, 921-963.

Baghat, S. \& Black, B. (2000). Board Independance and Long-Term Firm Performance. Columbia Law School, Law and Economics Working Paper, February.

Barberis, N., Boyko, M., Shleifer, A. \& Tsukonova, N. (1996). How does Privatization work? Evidence from Russian Shops. Journal of Political Economy, 104, 764-90.

Becht, M., Bolton, P. \& Roell, A. (2005). Corporate Governance and Control. ECGI Working Paper Series in Finance.

Berle, A. \& Means, G. (1932). The modern Corporation and Private Property (2rd ed.). New-York: Mac Millan. Bolbol A., Fatheldin, A. \& Omran, M. (2004).Financial Development, Structure, and Economic Growth: The Case of Egypt, 1974 - 2002. AMF Economic Paper No. 9, Abu Dhabi: Arab Monetary Fund.

Boubakri, N., Cosset, J-C. \& Guedhami, O. (2001). Liberalization, Corporate Governance and the Performance of Newly Privatized Firms. [Online] Available: http://www.papers.ssrn.com.

Bouton, D. (2002). Pour un meilleur gouvernement des entreprises cotées. Rapport du groupe de travail présidé par D. Bouton, MEDEF.

Brenner, S. N. \& Cochran, P. (1991).The Stakeholder Theory of the Firm: Implications for Business and Society Theory and Research. Annual Meeting of the International Association of Business and Society, Sundance, Utah. Carpenter M. A. \& Westphal, J. D. (2001). The strategic context of external network ties: Examining the impact of director appointments on board involvement in strategic decision making. Academy of Management Journal, 44(4), 639-660.

Castanias, R.P. \& Helfat, C.E. (2001). The managerial rents model: Theory and empirical analysis. Journal of Management, 27, 661-678.

Catelin, C. \& Chatelin, C. (2001). Privatisation, gouvernement d'entreprise et processus décisionnel: une intégration de la dynamique organisationnelle à travers le cas de France Télécom. Finance Contrôle Stratégie, $4(2), 63-90$.

Chatelin, C. (2003). Gouvernance partenariale et performance organisationnelle: les enseignements des privatisations passées. [Online] Available : http://perso.wandoo.fr/celine.chatelin.

Charreaux, G. (2002a).Variation sur le thème, à la recherche de nouvelles fondations pour la finance et la gouvernance d'entreprise. Finance Contrôle Stratégie, 5(3), 5-68.

Charreaux, G. (2002b). L'actionnaire comme apporteur de ressources cognitives. Revue Française de Gestion, 28(141), $77-107$.

Charreaux, G. \& Pitol-Belin, J.P. (1989). Image et réalités du conseil d'administration. Revue Française de Gestion, n 74.In G. Charreaux (ed.), Le gouvernement des entreprises. Economica, 1997.

Charreaux, G. (2004). Les théories de la gouvernance : de la gouvernance des entreprises à la gouvernance des systèmes nationaux. Cahier du FARGO, n 1040101 , Version révisée, décembre. 
Claessens, S. \& Djankov, S. (1998). Managers, Incentives and Corporate Performance: Evidence from the Czech Republic. mimeo, The World Bank, April.

Claessens, Stijn \& Djankov, S. (1998). Politicians and Firms in Seven Central and Eastern European Countries. The World Bank Policy Research Working Paper.

Donaldson, T. \& Preston, L. E. (1995).The stakeholder theory of the corporation: concepts, evidence, and implications. Academy of Management Review, 20(1), 63-91.

Earle, John, S. \& Estrin, S. (1997). Privatization Versus Competition: Changing Enterprise Behavior in Russia. William Davidson Institute Working Paper 70.

Faccio, M. \& Lang, L.H.P. (2002). The Ultimate Ownership of Western European Corporations. Journal of Financial Economics, 65(3), 365-395.

Fama, E. (1980). Agency Problems and the Theory of the Firm. Journal of Political Economy, 288-307.

Fama, M. \& Jensen, M. C. (1983a). Agency problems and residual claims. Journal of Law and Economics, 26, 327-349.

Fama, M. \& Jensen, M. C. (1983b). Separation of ownership and control. Journal of Law and Economics, 26, 301-325.

Freeman, R.E. \& Evan, W.M. (1990). Corporate Governance:a Stakeholder Interpretation. Journal of Behavioral Economics, 19, 337-359.

Freeman, R.E. (1984). Strategic management: a stakeholder approach. Boston: Pitman.

Frooman, J. (1999). Stakeholder Influence Strategies. Academy of Management Review, 24( 2), 191-205.

Godard, L. \& Schatt, A. (2004). Caractéristiques et fonctionnement des conseils d'administration français: un état des lieux. Université de Franche-Comté, Cahier du FARGO n 1040201.

Harrison, J.S., Hitt, M.A., Hoskisson, R.E. \& Ireland, R.D. (1991). Synergies and Post- acquisition Performance: Differences Versus Similarities in Resource Allocations. Journal of Management, 17(1), 173-190.

Hill \& Snell (1988). External control, corporate strategy, and firm performance in research intensive industries. Strategic Management Journal, 9, 577-90.

Jensen, M.C. \& Meckling, W.H. (1976). Theory of the firm: Managerial behavior, agency costs and ownership structure. Journal of Financial Economics, 3, 305-360.

Johnson, S. \& Shleifer, A., (2003). Privatization and corporate governance. In: Ito, T., Krueger, A.O. (Eds.), Governance, Regulation and Privatization. NBER-East Asia Seminar on Economics, vol. 12. The University of Chicago Press (forthcoming).

Jones, T. M. (1995). Instrumental stakeholder theory: a synthesis of ethics and economics. Academy of Management Review, 20(2), 404-437.

Judge, W.Q. \& Zeithaml, C.P. (1992). Institutional and Strategic Choice Perspectives on Board Involvement in the Strategic Decision Process. Academy of Management Journal, 35(4), 766-794.

Kogut, B. \& Zander, U. (1992). Knowledge of the Firm, Combinative Capabilities, and theReplication of Technology .Organization Science, 3, p. 383-397. In Foss N.(Eds.), Resources Firms and Strategies( pp. 306-326). Oxford University Press, 1997.

Lawrence, J. \& Stapledon, G.P., (1999). Is board compensation important? A study of listed Australian firms. Working paper, University of Melbourne.

Lazonick, W. \& O'Sullivan, M. (1998). Corporate Governance and the Innovative Economy: Policy Implications. STEP Report ISSN 0804-8185, Oslo.

López-de-Silanes \& Florencio (1997). Determinants of Privatization Prices. Quarterly Journal of Economics, 112, 965-1025.

Mace, M.L. (1971). Directors: Myth and Reality. Boston: Harvard Business School Press.

Melcher, R. (1996). The best and the worst boards. Business Week, November, 1996, 82-98.

Milliken, F.J. \& Martins, L. (1996). Searching for common threads: Understanding the multiple effects of diversity in organizational groups. Academy of Management Review, 21(2), 402-33.

Mintzberg, H. (2003). Le pouvoir dans les organisations. Editions d' Organisation, traduit de l'américain par Paul Sager( éd originale) : Power in and Out Organizations, 1983.

Mitchell, R. K., Agle, B. R. \& Wood, D. J. (1997). Toward a Theory of Stakeholders Identification and Salience: Defining the Principles of who and what really Counts. Academy of Management Review, 22(2), 833-886.

Mizruchi, M.S. (1996). What Do Interlocks Do? An Analysis, Critique, and Assessment of Research on Interlocking Directorates. Annual Review of Sociology, 22, 271- 298.

Morck (2004). Behavioral Finance in Corporate Governance - Independent Directors and Non-Executive Chairs. Harvard Institue of Economic Research, NBER, SSRN, [Online] Available: http://www.nber.org/papers/w10644.pdf, May. 
Nonaka, I. (1994). A Dynamic Theory of Organizational Knowledge Creation. Organization Science, 5(1), 14-37.

O'Sullivan, M. (2000). The Innovative Enterprise and Corporate Governance. Cambridge Journal of Economics, 24(4), 393-416.

Palmer, D., Jennings, P.D. \& Zhou, X. (1993). Late adoption of the multidivisional form by large U.S. corporations: Institutional, political and economic accounts. Administrative Science Quarterly, 17, 382-394.

Pfeffer, J. (1972). Size and Composition of Corporate Boards of Directors: the Organization and its Environment. Administrative Science Quarterly, 17, 218-228.

Prahalad, C.K. \& Hamel, G. (1990). The Core Competence of the Corporation. Harvard Business Review, 68(3), 79-91.

Prahalad, C.K. (1994). Corporate Governance or Corporate Value Added?: Rethinking the Primacy of Shareholder Value. Journal of Applied Corporate Finance, 6(4), 40-50.

Ricart, J.E. (2000). Comments on Rajan and Zingales, he Governance of the New Enterprise. In Vives X.(Eds.), Corporate Governance: Theoretical and Empirical Perspectives (pp. 229-232).Cambridge: Cambridge University Press.

Rindova, V. (1999). What Corporate boards have to do with strategy: A Cognitive perspective. Journal of Management Studies, 36, 953-975.

Roe, M.J. (2003). Political determinants of Corporate Governance - political context, Corporate impact. Oxford University Press.

Rumelt, R.P. (1984). Towards a Strategic Theory of the Firm. In Lamb R.B. (Eds.), Competitive Strategic Management. Upper Saddle River, NJ, Prentice Hall.

Shleifer, Andrei \& Vishny, R.W. (1997). A Survey of Corporate Governance. Journal of Finance, 52(2), 737-83. Teece, D.J., Pisano, G. \& Shuen, A. (1997). Dynamic Capabilities and Strategic management. Strategic Management Journal, 18(7), 509-533.

Useem, M. (1982). Classwide rationality in the politics of directors of large corporations in the United States and Great Britain. Administrative Science Quarterly ,27, 199-226.

Vermeulen, F. \& Barkema, H. (2001). Learning through Acquisitions. Academy of Management Journal, 44(3), 457-476.

Westphal, J.D. (1998).Boards Games: How CEOs Adapt to Increases in Structural Board Independence from Management. Administrative Science Quarterly, 43, 511-537.

Notes

Note 1 . Translated by the author.

Note 2. In accordance to Charreaux (2005) «gouvernement d'entreprise : performance et problèmes d'éthique», Revue française de gestion, vol 31, no 157, juillet-Aout 2005, p215-238.

Note 3. Translated by the author.

Note 4. Is qualified as residual, decision-making right «residual" decision» or the right to the approval of gain ' residual gain' which has not been specified comprehensively by contract, either because of the limits of rationality, or because of the establishment cost of the contract.

Note 5. Translated by the author.

Table 1. the shareholder representation of a governance system According to Charreaux 2002

\begin{tabular}{|l|l|l|}
\hline & \multicolumn{1}{|c|}{ Specific mechanisms to the firm } & non-specific mechanisms \\
\hline Intentional mechanisms & $\begin{array}{l}\text { Formal Systems of incitement and control } \\
\text { (example : managers remuneration system) }\end{array}$ & Legal and regulatory environment \\
\hline Spontaneous mechanisms & $\begin{array}{l}\text { Informal mechanisms: mutual monitoring of } \\
\text { managers ..... }\end{array}$ & $\begin{array}{l}\text { Market for directors } \\
\text { financial market } \\
\text { control market } \\
\text { Market of goods and services }\end{array}$ \\
\hline
\end{tabular}

A governance mechanism is considered as specific to the firm if it contributes to exclusively discipline the leaders of the firm (for example, the board of directors). A mechanism is said intentional if it has been envisaged in order to discipline the leaders. The intentional mechanisms are opposed to spontaneous mechanisms that can be market mechanisms for example (Charreaux 2002). 
Table 2. The cognitive representation of the governance system

\begin{tabular}{|c|c|c|}
\hline & Specific mechanisms to the firm & Non-specific mechanisms \\
\hline Intentional mechanisms & $\begin{array}{l}\text { Formal systems influencing the perception of } \\
\text { opportunities, organizational learning and cognitive } \\
\text { coordination (for example: the cognitive role of the } \\
\text { board of directors) }\end{array}$ & $\begin{array}{l}\text { Legal and regulatory environment through its } \\
\text { influence on the cognitive aspects. }\end{array}$ \\
\hline Spontaneous mechanisms & $\begin{array}{l}\text { Informal mechanisms affect the perception of } \\
\text { opportunities, organizational learning and cognitive } \\
\text { coordination (for example: the cognitive aspects of the } \\
\text { corporate culture) }\end{array}$ & $\begin{array}{l}\text { The markets apprehended through their } \\
\text { cognitive dimensions (exchange and acquisition } \\
\text { of knowledge) }\end{array}$ \\
\hline
\end{tabular}

Charreaux 2002

Table 3. Main theoretical perspectives for the analysis of CA

\begin{tabular}{|l|l|l|l|}
\hline Dimension & \multicolumn{1}{|c|}{ Role of CA } & $\begin{array}{l}\text { Disciplinary } \\
\text { Foundation }\end{array}$ & Main authors \\
\hline Agency theory & $\begin{array}{l}\text { Ensure the relationship between the shareholders and } \\
\text { the leaders in ensuring that the latter act in the interest } \\
\text { of the first. }\end{array}$ & Economy & $\begin{array}{l}\text { Jensen \& Meckling (1976) } \\
\text { Fama (1980) Jensen \& Fama } \\
(1985)\end{array}$ \\
\hline $\begin{array}{l}\text { Theory of the } \\
\text { managerial hegemony }\end{array}$ & $\begin{array}{l}\text { Legal fiction without real substance at best, advises the } \\
\text { leaders. }\end{array}$ & $\begin{array}{l}\text { Theory of } \\
\text { organizations }\end{array}$ & $\begin{array}{l}\text { Mace (1971) Lorsch \& McIver } \\
(1989)\end{array}$ \\
\hline $\begin{array}{l}\text { Theory of external } \\
\text { dependence }\end{array}$ & $\begin{array}{l}\text { Extend the borders of the company reduce uncertainty } \\
\text { of the environment }\end{array}$ & Sociology & $\begin{array}{l}\text { Pfeffer (1972 \& 1973) Pfeffer } \\
\text { \& Salancik (1978) Zald (1967) }\end{array}$ \\
\hline $\begin{array}{l}\text { Theory of } \\
\text { stakeholders }\end{array}$ & $\begin{array}{l}\text { Ensure the relationship between the leaders and the } \\
\text { whole of stakeholders in ensuring the necessary } \\
\text { arbitration. }\end{array}$ & $\begin{array}{l}\text { Theory of } \\
\text { organizations }\end{array}$ & $\begin{array}{l}\text { Freeman (1983) } \\
\text { Evan \& Freeman (1990) }\end{array}$ \\
\hline $\begin{array}{l}\text { Theory of } \\
\text { stewardship }\end{array}$ & $\begin{array}{l}\text { Ensures the stewardship of the assets of the } \\
\text { organization. }\end{array}$ & $\begin{array}{l}\text { Theory of } \\
\text { organizations }\end{array}$ & $\begin{array}{l}\text { Donaldson (1990) Davis et al. } \\
\text { (1997) }\end{array}$ \\
\hline Cognitive perspective & $\begin{array}{l}\text { Provide skills and managerial expertise } \\
\text { Expanding the spectrum of the perception of the leaders }\end{array}$ & $\begin{array}{l}\text { Cognitive } \\
\text { psychology }\end{array}$ & $\begin{array}{l}\text { Rindova (1999) Forbes \& } \\
\text { Milliken (1992) }\end{array}$ \\
\hline
\end{tabular}

Adapted and enriched from Zahra \& Pearce (1989) and Philip \& Stiles (2001), in accordance to Karoui and Khlif (2007) *Wafa, Montreal, xvith International Conference of Strategic Management 6-9 June 2007. 